\title{
Post-LSCS uterocutaneous fistula-utility of magnetic resonance imaging in its diagnosis
}

\section{LSCS sonrası uterokütan fistül-tanısinda manyetik rezonans görüntülemenin yararlılığı}

\author{
(1) Mohd Ilyas', (1) Insha Khan², (1) Tariq Gojwari ${ }^{1}$, (1) Musaib Ahmad Dar1, (1) Fahad Shafi1, (1) Obaid A Shah ${ }^{1}$ \\ 1Sher-I-Kashmir Institute of Medical Sciences, Department of Radiodiagnosis, Srinagar, India \\ 2Sher-I-Kashmir Institute of Medical Sciences, Department of Obstetrics and Gynecology, Srinagar, India
}

\begin{abstract}
The present report describes one of the rarest complications of cesarean section, uterocutaneous fistula, diagnosed on magnetic resonance imaging (MRI). A 37-year-old female with history of lower segment caesarean section (LSCS) four years previously presented with a chief symptom of discharge from the right end of a Pfannenstiel incision and on further evaluation was found to have uterocutaneous fistula arising from the LSCS scar to the right end of the abdominal incision. Uterocutaneous fistula is a rare delayed complication of LSCS and MRI plays a definitive role in the accurate diagnosis and delineation of the tract. The present case highlights that although rare, uterocutaneous fistulae must be kept in mind in patients presenting with discharge from the abdominal incision site and MRI evaluation should be performed in such cases for appropriate delineation of the tract.
\end{abstract}

Keywords: LSCS, uterocutaneous fistula, MRI

$\ddot{O} z$

Bu çalışmada; manyetik rezonans görüntüleme (MRG) ile tanısı konan ve sezaryen doğumun en nadir komplikasyonlarda biri olan uterokütan fistülün tanımlanması amaçlanmıştır. Dört yıl önce alt segment sezaryen öyküsü (LSCS) olan 37 yaşındaki kadın hasta, pfannenstiel insizyonunun sağ ucundan akıntı şikayeti ile başvurdu ve daha ileri değerlendirmelerde LSCS skarından abdominal insizyonun sağ ucuna kadar uterokütan fistülün olduğu tespit edildi. Uterokutanöz fistül, LSCS'nin nadir görülen gecikmiş bir komplikasyonudur ve MRG, alanın tam tanısında ve tasvir edilmesinde belirgin rol oynamaktadır. Buradaki olgu, abdominal insizyon bölgesinde akıntı nedeni ile başvuran hastalarda nadir olmasına rağmen, uterokutanöz fistülün akılda tutulması gerektiğini ve bu gibi durumlarda alanın uygun şekilde tasvir edilmesi için MRG değerlendirmesinin yapılması gerektiğini vurgulamaktadır.

Anahtar Kelimeler: LSCS, uterokütan fistül, MRG

\section{Introduction}

Uterine fistulae usually occur between the uterus and bowel or bladder (uterocolic or uterovesical) with uterocutaneous forming the rarest variety of uterine fistulae. The fistulae occur due to postoperative injuries or infections, use of drains, and incomplete closure of incision ${ }^{(1)}$. Uterocutaneous fistulae, being a rare condition, need appropriate diagnosis for which magnetic resonance imaging (MRI) plays the most important role, thereby helping in the proper delineation of the tract to guide the appropriate management ${ }^{(2)}$. The most common cause of uterocutaneous fistula is incomplete closure of the cesarean section wound. Earlier diagnosis can be made using fluoroscopic or cross-sectional modalities ${ }^{(3)}$. Surgical repair is the treatment of choice with preoperative gonadotropin administration showing better outcomes, but few cases may result in hysterectomy ${ }^{(3)}$. We describe this

PRECIS: To identify the possible risk factors for postpartum urinary retention.

Address for Correspondence/Yazışma Adresi: Mohd Ilyas MD,

Sher-I-Kashmir Institute of Medical Sciences, Department of Radiodiagnosis, Srinagar, India

E-mail: ilyasmir40@gmail.com ORCID ID: orcid.org/0000-0003-2030-8734

Received/Geliș Tarihi: 15.11.2018 Accepted/Kabul Tarihi: 07.02.2019

${ }^{\oplus}$ Copyright 2019 by Turkish Society of Obstetrics and Gynecology

Turkish Journal of Obstetrics and Gynecology published by Galenos Publishing House 
case of uterocutaneous fistula, which occurred 4 years after a caesarean section and was diagnosed using MRI.

\section{Case Report}

A 37-year old female with a history of lower segment cesarian section (LSCS) performed four years previously presented with the chief symptom of discharge from the incision site. MRI of the pelvis was performed, which revealed an enhancing fistulous tract originating from the site of the lower segment of the cesarean section and traversing through the parietal wall opening at the right edge of abdominal incision scar (Figure 1). The diagnosis of uterocutaneous fistula following LSCS was formulated. After exploratory laparotomy, excision of the tract was performed followed by administration of broadspectrum antibiotics with postoperative imaging showing no active tract (Figure 2). The patient remains under follow-up and is currently free of symptoms.

\section{Discussion}

During the era of classic cesarean section, a number of cases of uterocutaneous fistula were reported but with the advent of LSCS, the frequency has decreased to a large extent. Most uterocutaneous fistulae owe their origin to infections (e.g. genital tuberculosis) complicating uterine or abdominal scars. Besides LSCS, the causes of uterocutaneous fistulae include post septic abortion, placement of drain, missed uterine perforation following a diagnostic laparoscopy ${ }^{(4,5)}$.

Cases of post-partum hemorrhage wherein B-lynch sutures are placed have high risk of scar dehiscence, which may result in uterocutaneous fistula ${ }^{(6,7)}$. Other rare causes that may result in the formation of uterocutaneous fistula are patients with multiple abdominal myomectomies, history of hysterectomy, and as a primary presentation in underlying gynecologic malignancy such as endometrioid adenocarcinoma, which can predispose the weak cesarean scar to fistula formation ${ }^{(6-8)}$. The blood leakage from the incision site during menstruation has been described as pathognomonic of the uterocutaneous fistula ${ }^{(9)}$.

The various modalities that can be used in the diagnosis of uterocutaneous fistula include fistulography with injection of contrast through the skin site, hysterosalpingography with injection of contrast via cervix, computed tomography (CT) scanning, and MRI. Fistulography and hysterosalpingography define the fistulous tract but cannot provide details of its communication with the other intra-abdominal viscera ${ }^{(1,3)}$. CT imaging helps in the proper delineation of the tract after the injection of the contrast agent through the abdominal site, but soft tissue resolution of CT scans is less compared with $\mathrm{MRI}^{(10,11)}$. MRI provides good soft tissue resolution, avoids radiation (as all other investigations involve significant radiation doses), and helps in proper delineation of the fistulous tract and its relation to the surrounding viscera. The assessment of other pelvic organs with greater spatial resolution is possible. Intravenous contrast administration shows the enhancement of the granulation tissue along the fistulous tract, which gives a clue about the active status of the fistula. Further, contrast agent can also be administered via the abdominal site as in other investigations to check the patency of the $e^{(12)}$

Hence, MRI forms the best investigative modality in the assessment of uterocutaneous fistulae and other pelvic postoperative complications.

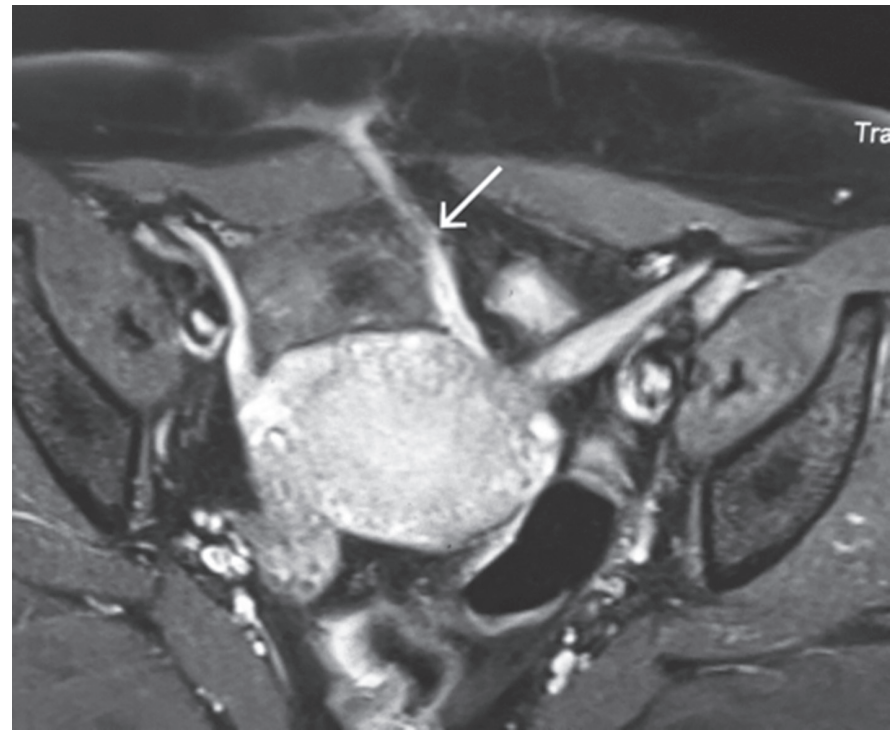

Figure 1. Post-contrast magnetic resonance image showing the enhancing fistulous tract (arrow) from the right end of the abdominal incision traversing through the abdominal cavity to the uterine wall

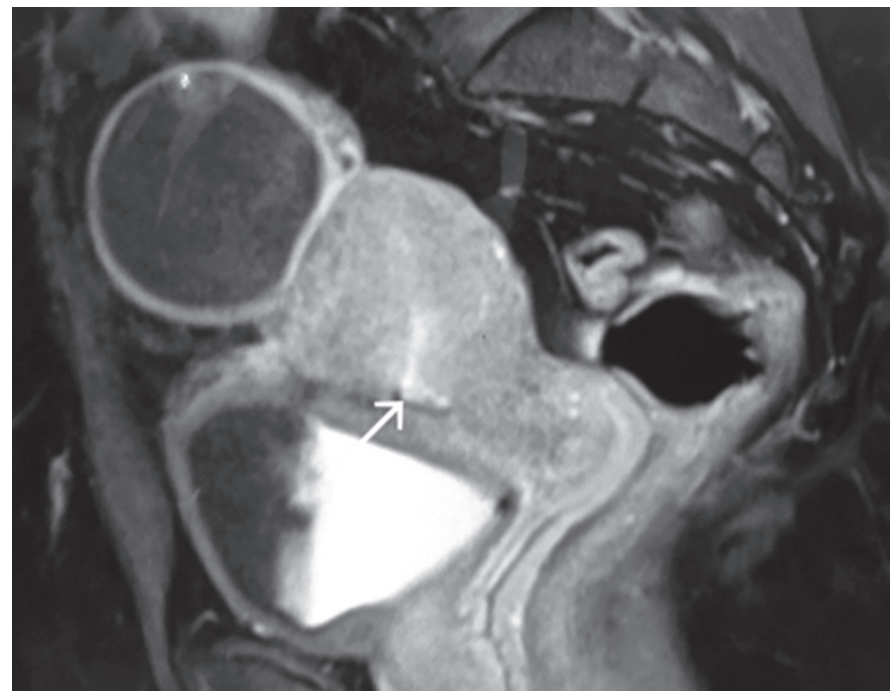

Figure 2. Post-surgical magnetic resonance image after 2 months, showing the LSCS scar (arrow) with no tract demonstrable. Additionally, she developed a simple ovarian cyst, which resolved on its own in 8 weeks

LSCS: Lower segment cesarian section 


\section{Ethics}

Informed Consent: Written and informed consent form was obtained from patient for possible publication of these images and the case details.

Peer-reviewed: Externally peer-reviewed.

\section{Authorship Contributions}

Concept: T.G., Design: T.G., Data Collection or Processing: T.G., Analysis or Interpretation: F.S., O.A.S., Literature Search: F.S, O.A.S., M.A.D., Writing: M.I., I.K.

Financial Disclosure: Nil.

Disclosure of Interests: There are no financial, personal, political, intellectual or religious interests.

\section{References}

1. Aggarwal R, Indiran V, Maduraimuthu P. Different etiologies of an unusual disease: colouterine fistula- report of two cases. Indian J Radiol Imaging 2018;28:37-40.

2. Yadav R, Rani PR, Jayalakshmi D. Uterocutaneous fistula. J Obstet Gynecol India 2006;56:81-2.

3. Rezael Z, Shahraki Z, Shirazi M. Utero-cutaneous fistula as arare complicationafter caesarean delivery: case series. J Obstet Gynecol Cancer Res 2017:2;e14071.

4. Jindal A, Chaudhary H, Thakur M. Tubercular utero-cutaneous fistula after caesarean section: a case report. Case Rep Women health 2018;17:3-4
5. Maddah G, Fattahi AS, Rahnama A, Jamshidi ST. Uterocutaneous fistula following cesarean section: successful management of a case. Iran J Med Sci 2016;41:157-60.

6. Thakur M, Rathore SS, Jindal A, Mahajan K. Uterocutaneous fistula following B-Lynch suture for primary postpartum hemorrhage. BMJ Case Rep 2018. pii: bcr-2017-223518. doi: 10.1136/bcr-2017223518

7. Taingson MC, Adze JA, Bature SB, Durosinlorun AM, Caleb M, Amina A. Uterocutaneous fistula following caesarean section. Niger J Surg Res 2016;17:58-60.

8. Hardy LE, Leung Y. Uterocutaneous fistula as the primary presentation of a gynaecological malignancy. BMJ Case Rep 2018; Available online June 2018.

9. Akkurt MO, Yavuz A, Tatar B, Ozkaya MO, Ekici EI. Uterocutaneous fistula after multiple abdominal myomectomies: a case report. Balkan Med J 2015;32:426-8

10. Thubert T, Denoiseux C, Faivre E, Naveau A, Trichot C, Deffieux $\mathrm{X}$. Combinedconservative surgical and medical treatmentof a uterocutaneous fistula. J Minim Invasive Gynecol 2012;19:244-7. doi: 10.1016/j.jmig.2011.10.010.

11. Vellanki VS, Gogineni S, Jahnavi KS. Case report of uterocutaneous fistula. J women's Health Care 2014;4:231.

12. Yadav R, Rani PR, Jayalakshmi D. Uterocutaneous fistula. J Obstet Gynecol India 2006;56:81-2. 